\title{
A fire probability model for forest stands in Catalonia (north-east Spain)
}

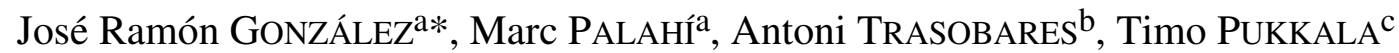 \\ ${ }^{a}$ Centre Tecnològic Forestal de Catalunya, Pujada del seminari s/n, 25280, Solsona, Spain \\ ${ }^{\mathrm{b}}$ ForEco Technologies, Av. Diagonal 416, Estudio 2, Barcelona 08037, Spain \\ ${ }^{\mathrm{c}}$ University of Joensuu, Faculty of Forestry, PO Box 111, 80101 Joensuu, Finland
}

(Received 25 April 2005; accepted 3 October 2005)

\begin{abstract}
The study presents a model for the probability of fire occurrence in forest stands of Catalonia. It was developed based on data from the Second Spanish National Forest Inventory (II IFN) and perimeters of the forest fires that occurred in Catalonia during a 12-year period that followed the II IFN measurement. The model was developed for forest planning, which means that the probability of fire was predicted from variables that are known in forest planning calculations. The model is suitable for both even-aged and uneven-aged stands, as well as pure and mixed stands. The variables included in the model represented easily measurable forest characteristics like elevation, tree size, stand structure and species composition. According to the model, the probability of a forest stand to become affected by forest fire increased with: lower altitudes, smaller diameters, larger basal areas, higher proportion of coniferous species and increasing variation in tree diameter. Although fire occurrence is a highly stochastic phenomenon, the model and all its parameters were significant, and the test results were consistent. The presented model can be used in stand and forest level optimizations that consider the effect of fire risk on optimal management.
\end{abstract}

fire / model / forest stands / Catalonia

Résumé - Modèle de probabilité de feux pour des peuplements forestiers de Catalogne (Nord-Est de l'Espagne). Cette étude présente un modèle pour les probabilités d'occurrence des feux dans des peuplements forestiers en Catalogne. Il a été développé sur la base de données du deuxième Inventaire Forestier National Espagnol (II IFN) et des périmètres des feux de forêts qui se sont produits en Catalogne pendant une période de 12 ans qui a suivi les mesures du II IFN. Le modèle a été développé pour la planification forestière ce qui veut dire que la probabilité de feux était prédite à partir de variables qui étaient connues dans les calculs de planification forestière. Le modèle est approprié pour les peuplements équiennes et inéquiennes, de même que pour les peuplements purs ou les peuplements mélangés. Les variables incluses dans le modèle sont des caractéristiques facilement mesurables comme l'altitude, la dimension des arbres, la structure des peuplements et les espèces constituant le peuplement. D'après le modèle, la probabilité qu'un peuplement forestier soit affecté par un feu augmente avec : une altitude basse, des petits diamètres, des surfaces terrières importantes, une forte proportion de conifères et une augmentation de la variation du diamètre des arbres. Bien que l'occurrence d'un feu soit un phénomène hautement stochastique, le modèle et tous ses paramètres étaient significatifs, et les résultats des tests étaient cohérents. Le présent modèle peut être utilisé à pour des optimisations, l'échelle du peuplement ou de la forêt, qui prennent en compte le risque de feu pour une gestion optimale.

feu / modélisation / peuplements forestiers / Catalogne

\section{INTRODUCTION}

Fire is a major component in many forested ecosystems and has a great influence on the ecological and economic functions of forest in these places. In the Mediterranean basin, fire has become a very serious problem during the last two decades and is currently the main cause of forest destruction, with an average burned area of 500000 ha per year [32]. In Catalonia, where $1288 \mathrm{~km}^{2}$ out of the total of $32000 \mathrm{~km}^{2}$ burned during the last decade [6], forest fires are perceived as the main environmental problem [22]. Therefore, active and preventive forest manage- ment through adequate fire risk reduction policies should have a high priority in Catalonia. In this context, a fire risk assessment model would be useful to assess forest management options with respect to fire risk issues.

Variables that affect the probability that a fire hits the stand may be divided into controllable and uncontrollable variables, on one hand, and variables of known and unknown values, on the other. Models used for predicting future states should employ predictors whose future value is known with reasonable accuracy. Of these variables, forest planning deals with controllable variables, i.e. variables that are under the control of

\footnotetext{
* Corresponding author: jr.gongalez@ctfc.es
} 
the forest manager. If a low occurrence of fire is a management objective, planning should find such values for the controllable variables that keep the probability of fire at an acceptable level.

Examples of variables that are both controllable and known to forest planning systems are stand density, species composition and vertical structure of the canopy. From previous research it is known that all these variables correlate with the likelihood of fire damage (e.g. [7, 19, 29]). By decreasing stand density, removing low canopy layers and favoring hardwood a manager may decrease the probability of fire damage and make it easier to extinguish the fire if it starts.

The probability of fire depends significantly on weather conditions (e.g. $[1,30])$. Unfortunately, the exact weather conditions of a particular forest in the future are not known, which means that models based on weather factors cannot be used in forest planning, the purpose of which is to predict the long-term consequences of management alternatives. On the other hand, the long-term averages of climatic factors are known, which means that they could be used as model predictors. The longterm averages of climatic factors correlate with site parameters such as longitude, latitude, elevation and aspect, implying that site parameters could replace climatic variables in modelling.

Many authors have remarked that the type, quantity and distribution of forest fuels affect fire occurrence and damage (e.g. $[15,31])$. The quantity and state of fuels is seldom known exactly in forest planning since the amount of deadwood and its state of decomposition are not usually measured or predicted. However, it may be assumed that the total amount and the characteristics of fuels correlate with growing stock and site characteristics, meaning that models based on stand and site characteristics may, to some extent, also account for the variation in fire probability caused by the quantity and properties of fuels.

Forest stands may be even-aged or uneven-aged, and the species mixture may vary. A risk model useful for forest planning should take stand structure and species composition into account and it should involve variables that are available in forest inventories. Such a model, based on empirical data, should be able to predict the effects of silvicultural treatments and types of management on the risk of fire in a given stand. The existent fire risk models seem not to fulfil all these requirements. Some predict age-dependent fire risk [18, 20], and others like the fire hazard rating model used by Thompson et al. [23], are based on qualitative expert assessments.

The aim of this study was to develop a stand-level model for the probability of fire adequate for forest management planning in Catalonia. The model should use variables that are normally measured in forest inventories in the region or otherwise available in forest management planning. The model should be able to predict the probability of fire occurrence for any forest stand in Catalonia, depending on the site and structure of the stand.

\section{MATERIALS AND METHODS}

\subsection{Inventory plots}

The modelling data comprised inventory data of forest stands, on one hand, and fire occurrence data, on the other hand. The data on for- est stands were obtained from the Second Spanish National Forest Inventory (II IFN) in Catalonia [9-12]. The IFN data consist of a systematic sample of permanent plots, distributed on a square grid of $1 \mathrm{~km}$, with a re-measurement interval of 10 years. The sampling method used circular plots with radius depending on the tree diameter at breast height (dbh, $1.3 \mathrm{~m}$ ): $5 \mathrm{~m}$ radius was used for trees with dbh between 7.5 and $12.4 \mathrm{~cm} ; 10 \mathrm{~m}$ for $12.5-22.4 \mathrm{~cm} ; 15 \mathrm{~m}$ for $22.5-$ $42.4 \mathrm{~cm}$; and $25 \mathrm{~m}$ for trees with dbh greater than or equal to $42.5 \mathrm{~cm}$. The following data were recorded for each sample tree: species, dbh, height, and distance and azimuth from the plot centre. Information about the abundance, mean height, and species composition of small trees $(\mathrm{dbh}<7.5 \mathrm{~cm})$ and bushes was also collected.

The II IFN in Catalonia took place in 1989 and 1990 and covered a surface area of $32114 \mathrm{~km}^{2}$. A total of 10855 inventory plots measured over the whole of Catalonia were used in this study. These plots represented 52 different forest types depending on the dominant species. The elevation of the plots ranged from sea level up to over $2300 \mathrm{~m}$.

\subsection{Fire data}

The fire data consisted of the perimeters of forest fires larger than 20 ha for the entire Catalonian region, collected during the 12-year period posterior to the II IFN (1991 to 2002). These fires accounted for approximately $95 \%$ of the total burned area. The fire perimeters were determined on a 1:50000 scale by the Department de Medi Ambient i Habitatge and the Institut Cartográfic de Catalunya as follows. The information of the fire reports (date of the fire, initiation coordinates, estimated area burned, etc.) was compared with images of the burned areas (LANDSAT, SPOT, CASI or ortophotos). For each fire, a file was created with georeferenced data from the affected area, both before and after the fire. The data were processed to estimate the effect of fire on the vegetation cover, using the Normalized Difference Vegetation Index (NDVI) [27] and principal components analysis. Digital classification was used for delineating the fire perimeter. A posterior control phase allowed a more accurate differentiation of the burned and unburned areas. Unburned areas that were inside the perimeters delineated in the first step were removed in the second step. A total number of 4699 burned areas were recorded during the 12 year period, corresponding to 231 fires, with a total area of 141317 ha.

\subsection{Data preparation}

After collecting the IFN and fire perimeter data, the next step was to indicate if the plots of the II IFN for Catalonia were burned during the studied period (1991-2002). A binary categorical variable was created, equalling 0 if the plot was not burned and 1 if the plot was burned. To obtain this information, spatial layers from both sets of data (IFN plots and fire perimeters) were overlaid using GIS tools (Arc Map 8.3). From this map, the IFN plots located within fire perimeters were classified as plots that were burned during the 12-years period. The data showed that 770 out of 10855 IFN plots were burned.

\subsection{Fire probability modelling}

Fire occurrence is a discrete event. Many distribution functions have been proposed for the analysis of a dichotomous outcome variable. Cox and Snell [3] discussed some of these. The logistic distribution was used since it is mathematically flexible, easy to use, and has a meaningful interpretation [8]. The logistic model offers a convenient way to constrain predictors to the interval $\{0,1\}$ [28]. After the model form and error structure was hypothesized, the key question was to specify a set of independent variables which could explain in a logical and statistically significant way the probability of a fire to occur in a given forest stand. Since the aim of the study was to develop a fire probability model applicable to forest management planning, 


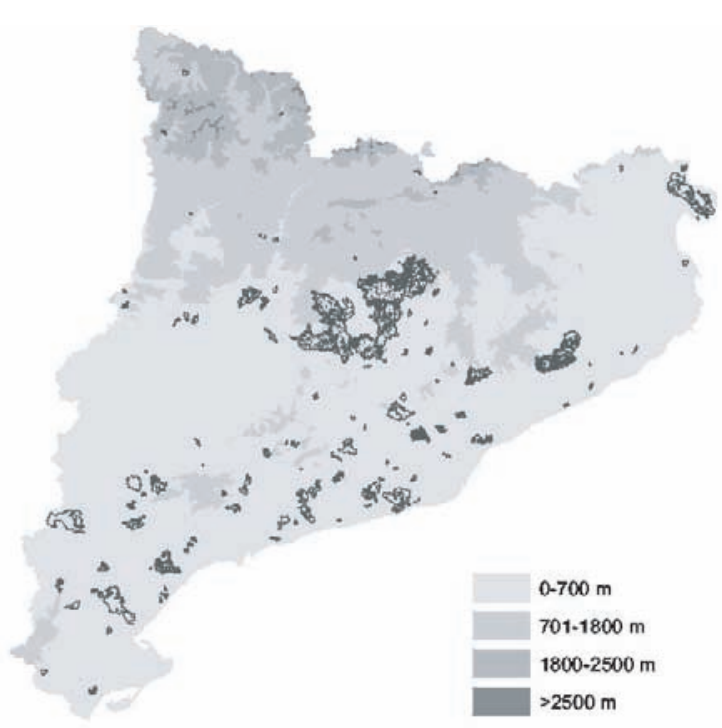

(a)

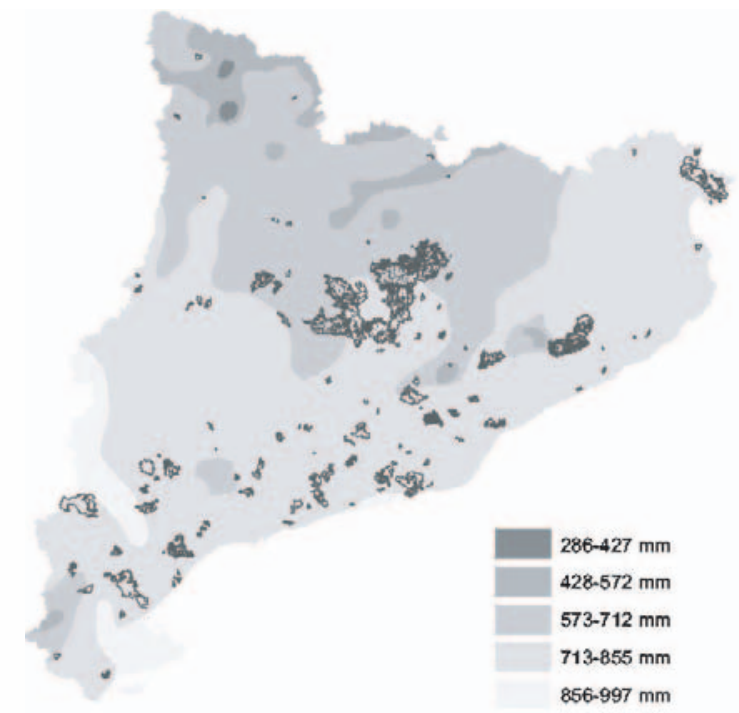

(b)

Figure 1. Elevation ranges (a) and the potential evapotranspiration of thermal regions (b): 855 to $997 \mathrm{~mm}$ in Mesothermic III (B'3), 712 to $855 \mathrm{~mm}$ in Mesothermic II (B'2), 572 to $712 \mathrm{~mm}$ in Mesothermic I (B'1), 427 to $572 \mathrm{~mm}$ in Mesothermic II (C'2), and 286 to $427 \mathrm{~mm}$ in Mesothermic I (C'1). Fire perimeters during 1991-2002 are shown in both maps.

variables that can be easily calculated from forest inventory data, or predicted using growth models (e.g., [24,25]), and which can be affected through forest management, were tested as potential predictors.

In this study, the primary sources of risk were assumed to be related to the structural and compositional characteristics of stands, as well as site factors. Therefore, a number of potential independent variables representing stand structure, species composition and site were tested. A logistic model to predict the probability of fire in a forest stand was fitted to the modelling data using the binary logistic procedure in SPSS. The predictors were selected taking into account three criteria. Firstly, log-likelihood ratio tests were used to determine whether the addition of the variable improved the model significantly. Secondly, the importance of the variable in terms of forest inventory and management as well as its simplicity was considered. Finally, the effect of adding the variable on the odds ratio of the variables already in the model was calculated. The odds for an event are defined as the probability that the event occurs divided by the probability that the event does not occur [13]. The odds ratio quantifies how many times more (or less) the event is likely to occur at the known levels of the predictors.

\section{RESULTS}

\subsection{Fire probability model}

After analysing several combinations of predictors and considering that all predictors had to be significant at the 0.05 level, the selected fire probability model was as follows:

See equation (1):

$$
\begin{aligned}
P_{\text {fire }} & =\left(1+\exp \left[-b_{0}+b_{1} \times \ln (\max \{\text { Ele }-6,1\})+b_{2} \times D g\right.\right. \\
& \left.\left.+b_{3} \times G+b_{4} \times P_{\text {hard }}+b_{5} \times\left(\frac{S D}{D G+0.01}\right)^{-1}\right]\right)^{-1}
\end{aligned}
$$

where $P_{\text {fire }}$ is the 12-year probability of fire occurring in a given stand, Ele is elevation (in hundreds of meters), $D g$ is the basalarea-weighted mean diameter $(\mathrm{cm})$ of trees, $G$ is the total basal area $\left(\mathrm{m}^{2} \mathrm{ha}^{-1}\right), P_{\text {hard }}$ is the proportion of hardwood species of the number of trees ha ${ }^{-1}$, and $S D$ is the standard deviation of the breast height diameters of trees $(\mathrm{cm})$. The last predictor $(S D /$ $(D g+0.01))$ expresses the relative variability of tree diameters. The variable is close to one in rather uneven stands and approaches to zero in homogeneous stands.

The logarithm of the maximum value of Ele- 6 and 1 was used to express the trend seen in the modeling data (Fig. 1) which indicates that most fires occur at elevations ranging from 0 to $700 \mathrm{~m}$. Beyond $700 \mathrm{~m}$ a.s.l. the fire occurrence declines sharply (see Fig. 1). Several other variables expressing site factors like latitude, aspect and continentality were also tested, as well as variables related to stand structure and species composition; like the amount of bushes, small trees and various species groups. However, the best fit was obtained with the variables given in equation (1), which gave a Nagelkerke $\mathrm{R}$ Square of 0.181. Collinearity statistics were calculated to detect the presence and severity of multicollinearity, and they showed no significant multicollinearity.

All variables included in the logistic model (Tab. I) were significant according to the Wald test $(p<0.05)$. The predictors included in the fire probability model may be divided roughly into three categories: variables describing stand structure, namely $G, D g$ and the ratio between $S D$ and $D g$; a variable describing the species composition $\left(P_{\text {hard }}\right)$ and a variable describing site (Ele). According to the model, the higher the elevation the lower is the probability of fire (Fig. 2). Furthermore, forest stands with higher values of $G$ and $S D$ have a higher probability 
Table I. Regression coefficient of equation (1), their standard deviations (S.E.) and statistical significance.

\begin{tabular}{lcccc}
\hline Variable & Coefficient & S.E. & Wald statistic & Significance \\
\hline Constant & -1.925 & 0.085 & 510.255 & 0.000 \\
$\ln (\max \{$ Ele $-6,1\})$ & -2.256 & 0.181 & 155.389 & 0.000 \\
$\mathrm{Dg}$ & -0.015 & 0.006 & 5.942 & 0.015 \\
$\mathrm{G}$ & 0.012 & 0.006 & 5.086 & 0.024 \\
$\mathrm{P}_{\text {hard }}$ & -1.763 & 0.121 & 211.328 & 0.000 \\
$S D /(D g+0.01)$ & 2.081 & 0.541 & 14.780 & 0.000 \\
\hline
\end{tabular}

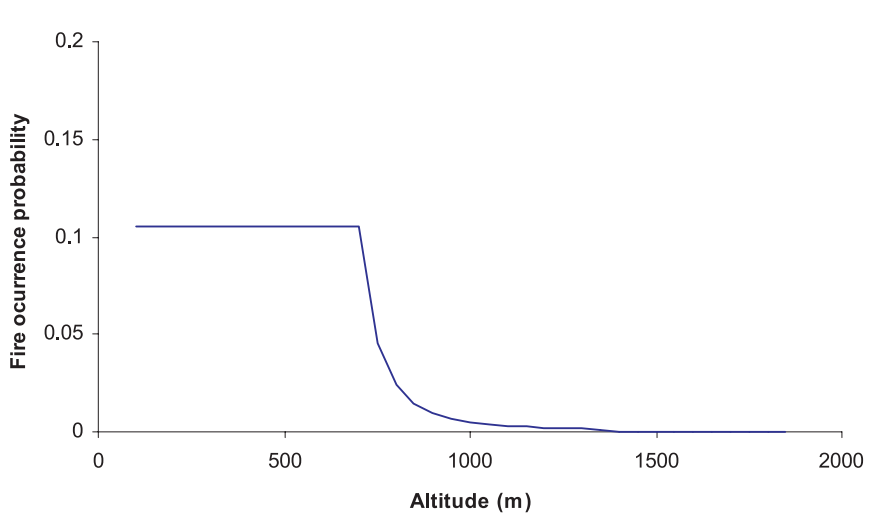

Figure 2. Effect of altitude on the probability of fire.
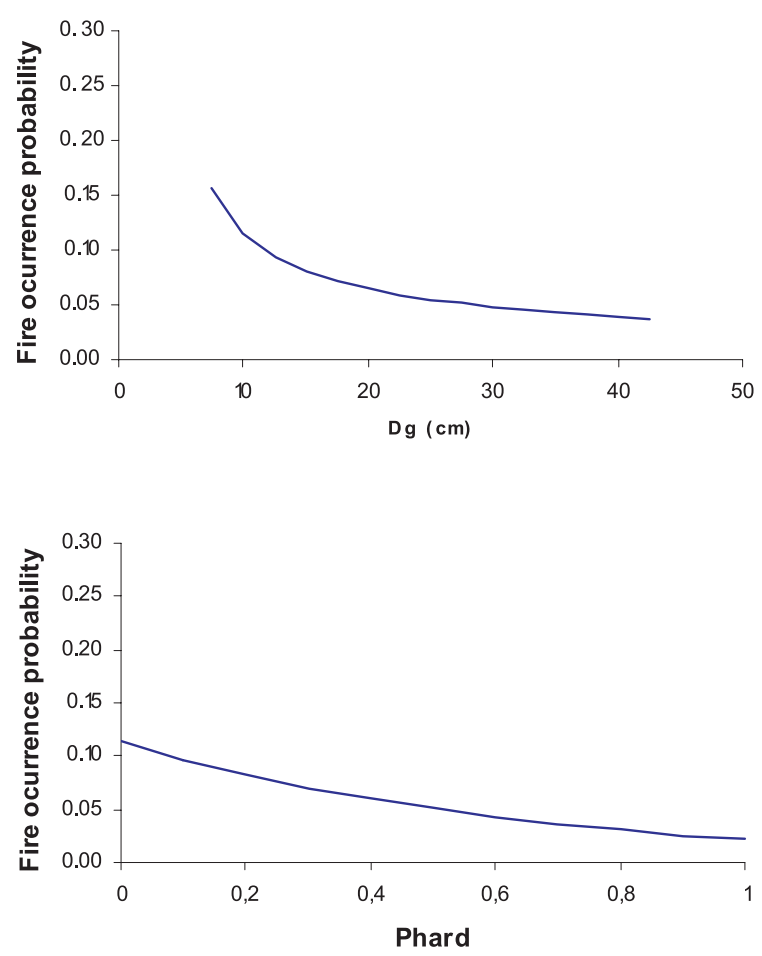

of fire (Fig. 3), while stands with higher values of $P_{\text {hard }}$ and $D g$ have a lower probability of fire (Fig. 3).

\subsection{Odds ratio analyses}

Due to the form of equation (1), the odds ratio of several predictors could not be obtained as by exponentiating the value of the predictor [8]. For example, Ele and $D g$ do not have a constant odds ratio across their different values since Ele is introduced in a logarithmic form and $D g$ appears twice, once as such and the other time in the variability ratio. Therefore, the odds ratios were computed by exponentiating the algebraic difference between the logits at two reasonable levels of the risk factor being compared. In this way, the odds ratios for different units of change could be analyzed.

From the analyses conducted it can be interpreted that a $100 \mathrm{~m}$ decrease of elevation, from $800 \mathrm{~m}$ to $700 \mathrm{~m}$, would
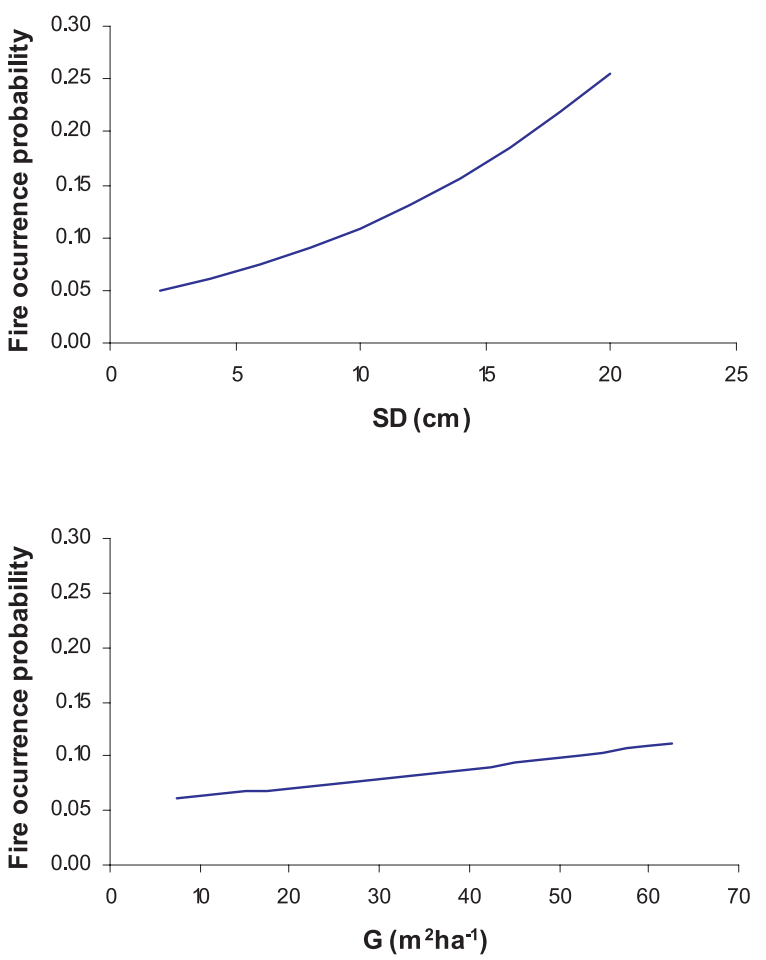

Figure 3. Effect of basal-area-weighted mean diameter $(D g)$, standard deviation of dbh $(S D)$, proportion of hardwood in number of trees $\left(P_{h a r d}\right)$, and total basal area $(G)$ on the probability of fire. 


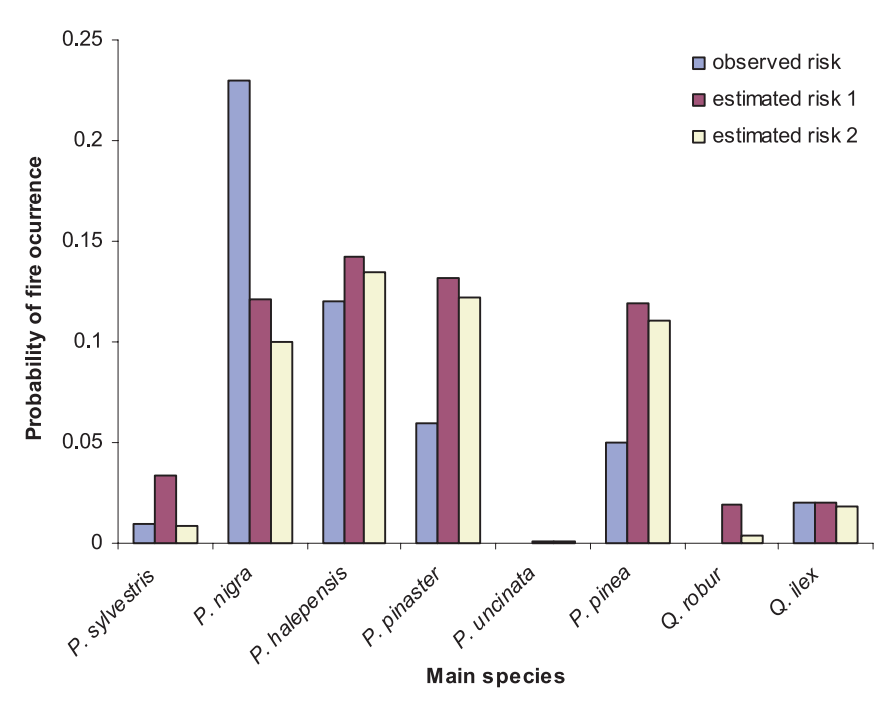

Figure 4. Twelve-year probability of fire for stands with different main species as observed, calculated from the mean of the risks estimated for each inventory plot, and estimated using the average values of predictors in plots with different main species.

increase the probability of fire by almost 5 times. However, the same decrease $(100 \mathrm{~m})$ happening from $1400 \mathrm{~m}$ to $1300 \mathrm{~m}$ would increase the probability by only 1.35 times. On the other hand, a change of $100 \mathrm{~m}$ from any elevation lower than or equal to 700 would not have any effect on the probability of fire. The effect of a change in $D g$ had also an important effect on the probability of fire, but it was not constant across different values. For example, a change of $D g$ from $45 \mathrm{~cm}$ to $15 \mathrm{~cm}$ in a stand with a value of $S D$ of 10 (very uneven stand) would increase the probability of fire by 4 times. However, the same change in a stand with $S D$ equal to zero (completely homogeneous stand) would increase the probability by only by 1.6 times.

Another model predictor having a strong relative effect was $P_{\text {hard }}$. The odds ratio for this predictor shows that a change of 0.1 in this predictor would increase the probability of fire by 1.2 times. A change of $P_{\text {hard }}$ from 1 (pure hardwood stand) to 0 (pure coniferous stand) would increase the probability of fire by 5.8 times. In the case of $G$, the change of odds per one unit change of the variable did not have a strong relative effect. An increase of $10 \mathrm{~m}^{2} \mathrm{ha}^{-1}$ would increase the risk of fire by 1.2 times. Finally, the variability ratio had also a very strong relative effect; a change from 0.1 (even stand) to 1 (rather uneven stand) would increase the probability of fire by 6.5 times.

\subsection{Predicted probability by species}

Figure 4 shows the predicted vs. observed 12-year fire probability rates of plots with different main species. The overall trend of predictions for different species is logical and close to the observed fire occurrence. Predictions for Pinus pinea and Pinus pinaster are higher than the observed fire occurrence, while the predictions for stands dominated by Pinus nigra are lower than the observed one. The last result can be explained by the catastrophic fires of 1994 and 1998, which destroyed together almost 30000 ha of Pinus nigra stands [4, 5]. The dif- ference between the predicted and observed fire probabilities in stands dominated by Pinus pinaster and Pinus pinea can be explained by the small proportion of these type of forests in Catalonia; the observed risk may be an underestimate in the longer run whereas the model predictions seem logical.

\subsection{Application example}

To evaluate the effects of potential management actions, the fire risk model was used to compute the probability of fire for several forest stands with an elevation of $700 \mathrm{~m}$ but different size structures and species compositions. The 12 -year fire probability was 0.209 for the pure coniferous stand with unevenaged structure (Fig. 5a). The stand resembling a two-layered dense structure (Fig. 5b) had also a high probability (0.192). These results can be explained by the high values of $S D(9.2$ and $12.7 \mathrm{~cm}$, respectively for the uneven and the two-layered stands), while $D g$ was not extremely high and the percentage of hardwoods was zero. Figures $5 \mathrm{c}$ and $5 \mathrm{~d}$ show how the probability of fire can be modified by two different management operations with a starting point in Figure 5b. A complete removal of the lower tree layer present in Figure $5 \mathrm{~b}$ would mean a reduction of fire risk from 0.192 to 0.090 (Fig. 5c). A heavy high thinning in the stand of Figure $5 \mathrm{~b}$ reduces the probability of fire from 0.192 to 0.160 which is much less than the effect of low thinning (Fig. 5d).

Figure 5e shows the probability of fire for a two-layered stand with the same structural characteristics as in the stand of Figure 5b except that the lower story consists of hardwoods. As result of the high percentage of hardwoods $\left(P_{\text {hard }}=0.87\right)$ the probability of fire is low. Figures $5 \mathrm{f}, 5 \mathrm{~g}$ and $5 \mathrm{~h}$ show the probability of fire for pure hardwood stands with different stand structures. Of these, the probability was the lowest for the sparse stand resembling a mature stage, and highest for the twolayered stand of Figure 5f. The stands in Figures 5f, 5g and 5h have the same structural characteristics as the stands in Figures $5 b, 5 c$ and $5 d$, respectively, differing only in species composition.

\section{DISCUSSION}

The fire probability model for forest stands in Catalonia presented in this study opens many possibilities to integrate the risk of fire into forest management planning and decision-making. The parameters included in the model represented easily measurable forest characteristics such as elevation, tree size, structure and species composition. Some of these variables, namely stand structure and species composition are under the control of the forest manager, which permit a forest landowner to have the reduction of fire risk as a management objective in numerical planning calculations. The variables included in the model were assumed to have a clear relationship with variables normally used to explain potential fire behavior. For example, stand composition and structure have a clear effect on the amount and vertical distribution of aerial fuels, and they also affect the amount of ground vegetation and deadwood through competition and suppression processes. Even microclimatic conditions inside the forest stand are partially regulated by canopy closure and light interception. Another model variable with 

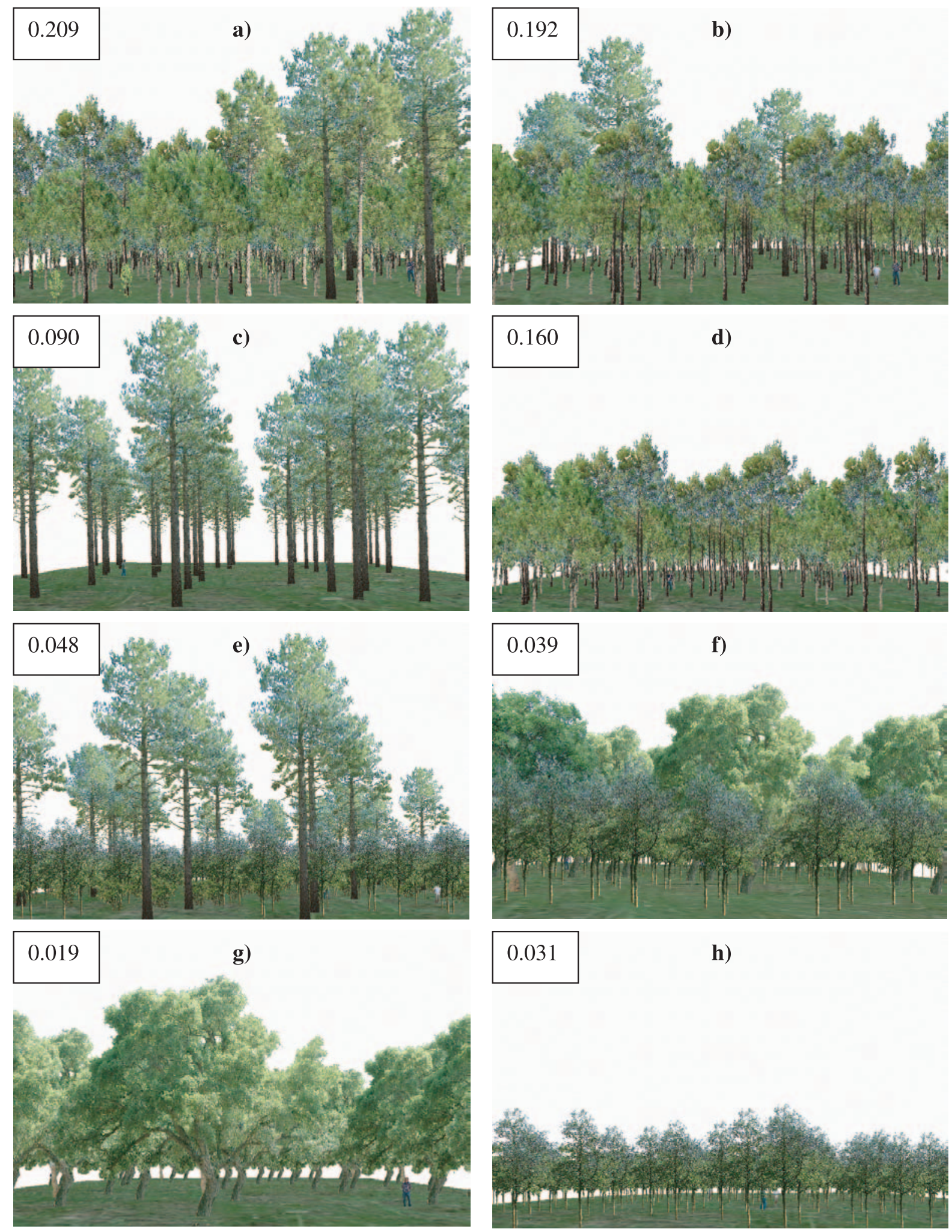

Figure 5. Fire risk depending on stand structure and composition. 
a great influence on fuel moisture is elevation which correlates with precipitation and temperature.

Elevation appeared to be a very important variable in terms of odds ratio. As shown in Figure 1, the number and sizes of fires decrease sharply above $700 \mathrm{~m}$ a.s.l. It is also evident from Figure 1 that evapotranspiration is highly correlated with elevation, which can explain the importance of this variable. The non-linear relationship of this variable with a constant fire probability below a limiting elevation is consistent with a previous study by Schoenberg et al. [21] who report a non-linear effect of fuel moisture, temperature and precipitation on the burned area, the burned area changing with these variables up to a certain threshold. Other factors related to elevation like the presence of people could also play a role. However, further research is needed to expand the model to include socio-economic and infrastructural variables such as density of people and proximity of roads.

Species composition of the stand is an important factor for fire, and it was included in the model through the $P_{\text {hard }}$ variable. This predictor is crucial to explain the significant difference between fire occurrence in coniferous and hardwood stands present in the modelling data. Many authors (e.g. [2, 28]) have pointed out the high inflammability of coniferous species due to their high content of resin and essential oils, which make them vulnerable to fire. The other model predictors explain the effect of several forest stand characteristics on the probability of fire. The parameters of these predictors support previous knowledge which states that stands resembling mature sparse even-aged forests have a lower fire risk than dense and multilayered stands [19].

The logistic model has been used earlier for predicting wind and snow damage probability as a function of stand variables $[13,16]$, but no management-oriented model for the probability of fire occurrence has been presented so far based on empirical data. The model enables the quantification of the effects of management on the probability of fire and therefore allows for the development of silvicultural strategies that take the risk of fire into account. For instance, the model can be used in standlevel optimization studies [26] to find the optimal management for different species and stand structures taking into account the probability of fire. Landscape level forest planning studies can also be conducted based on the fire probability model; the probability can be calculated for each of the stands in the landscape and then spatial optimization techniques can be used to reduce the continuity of risky stands or to create a fragmented landscape with respect to high risk stands [15]. The model presented has also use in forest policy planning, enabling scenario analyses of policy alternatives to take the risk of fires into account.

The National Forest Inventory plots (IFN II) and the fire perimeter data for Catalonia provide an outstanding database in terms of size and representation of forest conditions in Catalonia. During the study period, according to historical fire records, fires bigger than 20 ha account for over $95 \%$ of the forest area burned in Catalonia. The 12-year fire period used for the study gives also representative information about the fire regime in the region. However, since fire is a very erratic event, longer observation periods will certainly enable future improvements in the model.
The purpose of risk models is to estimate the probability that a hazardous event will happen during a period of time in a certain place. Due to the highly stochastic nature of many disturbances like forest fires, the probability does not give us a certain answer if the event will really happen in that place during that period of time. In the case of fire the prediction becomes especially uncertain in small areas and short periods of time, where the influence of ignition points of adjacent areas is great [14, 17]. The presented model gives us a clue about the endogenous stand factors that affect fire probability, and how the probability can be modified by varying these factors through forest management.

Acknowledgements: The authors want to thank the members of the Servei de Prevenció d'Incendis Forestals of Catalonia for providing the fire data used in this study. This study is enclosed in the EFORWOOD project and has been conducted within the MEDFOREX program coordinated by the Forest Technology Centre of Catalonia. We are grateful to Mr. David Gritten for the linguistic revision of the manuscript.

\section{REFERENCES}

[1] Andrews P.L., BEHAVE: Fire behavior prediction and fuel modeling system-BURN subsystem, Part 1, Gen. Tech. Rep. INT-194. Ogden, UT: US Department of Agriculture, Forest Service, Intermountain Research Station, 1986, 130 p.

[2] Bond W.J., Van Wilgen, B.W., Why and how do ecosystems burn? Fire and Plants, Chapman \& Hall, 1996, pp. 17-33.

[3] Cox D.R., Snell E.J., Analysis of Binary Data, 2nd ed., Chapman \& Hall, London, 1989, 236 p.

[4] DGCN, Los incendios forestales en España durante el año 1994, Dirección General de Conservación de la Naturaleza, MMA, Madrid, 1994.

[5] DGCN, Los incendios forestales en España durante el año 1994, Dirección General de Conservación de la Naturaleza, MMA, Madrid, 1998.

[6] DGCN, Los incendios forestales en España. Decenio 1991-2000, Dirección General de Conservación de la Naturaleza, MMA, Madrid, 2002.

[7] Finney M.A., Modeling the spread and behavior of prescribed natural fires, Proc. 12th Conf. Fire and Forest Meteorology, 1994, pp. 138-143.

[8] Hosmer D.W., Lemeshow S., Applied logistic regression, 2nd ed., Wiley, Series in Probability and Statistics, New York, 2000.

[9] ICONA, Segundo Inventario Forestal Nacional (1986-1995) Cataluña: Barcelona, MAPA, Madrid, 1993.

[10] ICONA, Segundo Inventario Forestal Nacional (1986-1995) Cataluña: Girona, MAPA, Madrid, 1993.

[11] ICONA, Segundo Inventario Forestal Nacional (1986-1995) Cataluña: Lleida, MAPA, Madrid, 1993.

[12] ICONA, Segundo Inventario Forestal Nacional (1986-1995) Cataluña: Tarragona, MAPA, Madrid, 1993.

[13] Jalkanen A., Mattila U., Logistic regression models for wind and snow damage in northern Finland based on the National Forest Inventory data, For. Ecol. Manage. 135 (2000) 315-330.

[14] Li C., Apps M.J., Effects of contagious disturbance on forest temporal dynamics, Ecol. Model. 87 (1996) 143-151.

[15] Loehle C., Applying landscape principles to fire hazard reduction, For. Ecol. Manage. 198 (2004) 261-267.

[16] Lohmander P., Helles F., Windthrow probability as a function of stand characteristics and shelter, Scan. J. For. Res. 2 (1987) 227-238.

[17] McCarthy M.A., Gill A.M., Bradstock R.A., Theoretical fire interval distributions, Int. J. Wildl. Fire 10 (2001) 73-77. 
[18] Moritz M.A., Spatiotemporal analysis of controls on shrubland fire regimes: age dependency and fire hazard, Ecology 84 (2003) 351361.

[19] Pollet J., Omi P.N., Effect of thinning and prescribed burning on crown fire severity in ponderosa pine forests, Int. J. Wildl. Fire 11 (2002) 1-10.

[20] Reed W., Estimating the Historic Probability of Stand-Replacement Fire Using the Age-Class Distribution of Undisturbed Forest, For. Sci. 40 (1994) 104-119.

[21] Schoenberg F.P., Peng R., Huang Z., Rundel P., Detection of nonlinearities in the dependence of burn area on fuel age and climatic variables, Int. J. Wildl. Fire 12 (2003) 1-6.

[22] Tábara D., La percepció dels problemes del medi ambient, Beta Editorial, Barcelona, 1996.

[23] Thompson W.A., Vertinsky I., Schreier H., Blackwell B.A., Using forest fire hazard modelling in multiple use forest management planning, For. Ecol. Manage. 134 (2000) 163-176.

[24] Trasobares A., Pukkala T., Miina J., Growth and yield model for uneven-aged mixtures of Pinus sylvestris L. and Pinus nigra Arn. in Catalonia, north-east Spain, Ann. For. Sci. 61 (2004) 9-24.

[25] Trasobares A., Pukkala T., Using past growth to improve individual-tree diameter growth models for uneven-aged mixtures of
Pinus sylvestris L. and Pinus nigra Arn. in Catalonia, north-east Spain, Ann. For. Sci. 61 (2004) 409-417.

[26] Trasobares A., Pukkala T. Optimising the management of unevenaged Pinus sylvestris L. and Pinus nigra Arn. mixed stands in Catalonia, north-east Spain, Ann. For. Sci. 61 (2004) 747-758.

[27] Tucker C.J., Vanpraet C., Sharman M.J., Vanfnttersum G., Satellite remote sensing of total herbaceous biomass production in the Senegalese Sahel: 1980-1984, Remote Sens Environ. 17 (1985) 233249.

[28] Vanclay J.K., Modelling forest growth and yield. Applications to mixed tropical forests, CAB International, Wallingford, 1994,312 p.

[29] Van Wagner C.E., Conditions for the start and spread of crown fire, Can. J. For. Res. 7 (1977) 23-34.

[30] Van Wagner C.E., Development and structure of the Canadian Forest Fire, Weather Index System, Can. For. Serv., Ottawa, Ont., For. Tech. Rep. 35, 1987, 37 p.

[31] Velez. R., Mediterranean forest fires: A regional perspective, Unasylva 162 (1990) 10-12.

[32] Velez R., Causes of fires in the Mediterranean Basin, EFI proceedings 45 (2002) 35-42. 